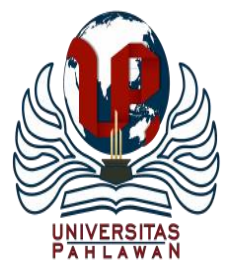

Edukatif : Jurnal Ilmu Pendidikan Volume 3 Nomor 4 Tahun 2021 Halm 1451 - 1459

EDUKATIF: JURNAL ILMU PENDIDIKAN

Research \& Learning in Education

https://edukatif.org/index.php/edukatif/index

\title{
Pengaruh Motivasi Belajar dan Manajemen Kelas terhadap Hasil Belajar Siswa
}

\author{
Agung Hidayatullah \\ Magister Manajemen Pendidikan, Universitas Jambi, Indonesia \\ E-mail : agunghidayatullahagutri@gmail.com
}

\begin{abstract}
Abstrak
Tujuan dari penelitian untuk mengetahui pengaruh motivasi belajar dan manajemen kelas terhadap hasil belajar siswa. Penelitian menggunakan metode kuantitatif dengan teknik korelasi metode. Pengumpulan data instrumen berupa angket. Populasi penelitian adalah 117 orang dan sampelnya 43 orang. Penelitian menggunakan beberapa uji regresi dengan uji hipotesis pada taraf signifikansi 0,05. Hasil penelitian menunjukkan bahwa terdapat pengaruh yang signifikan berdasarkan hasil uji Annova nilai signifikansi 0,000 dapat dinyatakan bahwa variabel pengelolaan kelas dan pembelajaran secara simultan atau bersama-sama berpengaruh signifikan terhadap variabel hasil belajar. Berdasarkan uji R diperoleh 0,971 menunjukkan bahwa korelasi atau hubungan antara variabel hasil belajar dan nilai variabel motivasi belajar dan pengelolaan kelas termasuk dalam kategori sangat kuat, dapat diartiak 94,3\% variasi pembelajaran hasil dapat dijelaskan oleh variabel dependen manajemen kelas dan motivasi belajar yang digunakan dalam persamaan regresi. Sisanya 4,7\% dijelaskan oleh variabel lain di luar penelitian ini.
\end{abstract}

Kata kunci : Motivasi Belajar, Manajemen Kelas dan Hasil Belajar.

Abstract

The purpose of the study was to determine the effect of learning motivation and classroom management on student learning outcomes. The research uses quantitative methods with method correlation techniques. Instrument data collection is in the form of a questionnaire. The research population was 117 people and the sample was 43 people. The study used several regression tests with hypothesis testing at a significance level of 0.05. The results showed that there was a significant effect based on the results of the Annova test, a significance value of 0.000. It can be stated that the classroom management and learning variables simultaneously or jointly have a significant effect on the learning outcome variables. Based on the $R$ test, it was obtained 0.971 indicating that the correlation or relationship between the learning outcomes variables and the value of the learning motivation and classroom management variables was included in the very strong category, it could be interpreted that $94.3 \%$ of the variation in learning outcomes could be explained by the dependent variable class management and learning motivation used in regression equation. The remaining $4.7 \%$ is explained by other variables outside this study.

Keywords: Learning Motivation, Class Management and Learning Outcomes.

Copyright (c) 2021 Agung Hidayatullah

$\triangle$ Corresponding author

Email : agunghidayatullahagutri@gmail.com

DOI : https://doi.org/10.31004/edukatif.v3i4.620

ISSN 2656-8063 (Media Cetak)

ISSN 2656-8071 (Media Online)

Edukatif : Jurnal Ilmu Pendidikan Vol 3 No 4 Tahun 2021 p-ISSN 2656-8063 e-ISSN 2656-8071 


\section{PENDAHULUAN}

Peserta didik yang sedang mengikuti proses pembelajaran baik pada tingkat dan jenjang pendidikan tertentu, tentunya menginginkan hasil belajar yang baik (Harahap, et al., 2021). Pendidikan sebagai usaha membina dan mengembangkan pribadi manusia dari aspek-aspek rohaniah dan jasmaniah juga harus berlangsung secara bertahap. Oleh karena suatu kematangan yang bertitik akhir pada optimalisasi perkembanga atau pertumbuhan, baru dapat tercapai bilamana berlangsung melalui proses demi proses kearah tujuan akhir perkembangan atau pertumbuhan (Enkoswara, 2011).

Di madrasah Tsanawiyah ini sebagai tempat riset oleh peneliti tidak sedikit siswa yang memiliki motivasi belajar rendah. Untuk membantu siswa yang memiliki motivasi belajar rendah perlu dilakukan suatu upaya dari guru agar siswa yang bersangkutan untuk dapat meningkatkan motivasi belajarnya. Salah satu penghambat kesuksesan remaja adalah kurangnya motivasi. Untuk mengembangkan pemikiran kreatif, kita harus mempunyai motivasi yang cukup. Motivasi akan membuat kita bersemangat untuk merealisasikan apa yang ada dalam imajinasi kreatif kita.

Menurut Mawarsih (Harahap, et al., 2021) keberhasilan belajar sering disebabkan adanya motivasi yang kuat. Dalam penelitian ini guru yang sangat disorot adalah wali kelas yang bertugas sebagai manajer di dalam kelas yang dalam hal ini merupakan salah satu aspek yang ikut diteliti dalam karya tulis ilmiah. Peran seorang wali kelas dalam manajemen kelas berperan penting dalam proses belajar mengajar seorang manajer kelas harus mengetahui tentang bagaimana kelas tersebut masuk ke jenis kelas yang dapat diamati oleh manager.

Pada mata pelajaran aqidah akhlak merupakan mata pelajaran yang akan peneliti ambil sebagai sampel dari beberapa mata pelajaran yang ada, dikarenakan pada mata pelajran ini siswa banyak yang lebih merasa pelajaran yang tidak terlalu penting padahal sabagai lembaga pendidikan agama mata pelajaran aqidah akhlak ini sangatlah penting. Bertitik tolak dari uraian diatas, penulis tertarik untuk melakukan penelitian tentang pengaruh motivasi belajar dan manajemen kelas terhadap hasil belajar siswa.

Rumusan masalah yang akan di bahas dalam karya ilmiah yaitu adakah pengaruh motivasi belajar yang signifikan terhadap hasil belajar siswa, adakah pengaruh manajemen kelas yang signifikan terhadap hasil belajar siswa, adakah pengaruh motivasi belajar dan manajemen kelas yang signifikan terhadap hasil belajar siswa. Tujuan yang ingin dicapai dalam penelitian ini adalah untuk mengetahui pengaruh motivasi belajar terhadap hasil belajar siswa, untuk mengetahui pengaruh manajemen kelas terhadap hasil belajar, untuk mengetahui pengaruh motivasi belajar dan manajemen kelas terhadap hasil belajar.

Hasil penelitian dapat dipergunakan peneliti lanjut sebagai bahan referensi untuk meningkatkan kualitas pendidikan bila dihubungkan dengan motivasi belajar dan manajemen kelas serta hasil belajar siswa dan dapat melakukan penelitian lanjutan yang lebih luas dan mendalam. Pentingnya penelitian ini dilakukan karena mengingat pentingnya peranan motivasi bagi siswa dalam belajar, maka guru diharapkan dapat membangkitkan dan meningkatkan motivasi belajar siswa-siswanya. Agar siswa dapat mencapai hasil belajar yang optimal, maka siswa harus memiliki motivasi belajar yang tinggi, walaupun pada kenyataannya tidak semua siswa memiliki motivasi belajar yang tinggi dalam belajar.

Hipotesis dalam penelitian ini peneliti jabarkan sebagai berikut:

Ha1 : Adanya pengaruh yang signifikan antara motivasi belajar denganHasil belajar di Madrasah Tsanawiyah X Kabupaten Tebo

Ho1 : Tidak ada pengaruh yang signifikan antara motivasi belajardengan hasil belajar di Madrasah Tsanawiyah X Kabupaten Tebo2.

Ha2 : Adanya pengaruh antara manajemen kelas terhadap hasil belajarsiswa di Madrasah Tsanawiyah X Kabupaten Tebo

Ho2 : Tidak ada pengaruh antara menajemen kelas terhadap hasilbelajar siswa di Madrasah Tsanawiyah X Kabupaten Tebo3

Ha3 : Terdapat korelasi atau hubungan serta pengaruh motivasi belajardan manajemen kelas terhadap 
hasil belajar siswa di Madrasah TsanawiyahX Kabupaten Tebo

Ho3 : Tidak terdapat korelasi atau hubungan serta pengaruh motivasibelajar dan manajemen kelas terhadap hasil belajar siswa di MadrasahTsanawiyah X Kabupaten Tebo

Menurut Hintzman (Muhibin, 2014) Belajar adalah sesuatu perubahan yang terjadi dalam diri organisasi manusia atau hewan disebabkan oleh perubahan pengalaman yang dapat mempengaruhi tingkah laku organisme tersebut. Hasil belajar merupakan hasil dari suatu interaksi tindak belajar dan tindak mengajar. Dari sisi guru, tindak mengajar diakhiri dengan proses evaluasi hasil belajar. Dari sisi siswa, hasil belajar merupakan berakhirnya penggal dan puncakproses belajar (Dimyati \& Mudjiono, 2019). Menurut Egok (Riyanti, Wahyudi, \& Suhartono, 2021) ada dua faktor yang memengaruhi hasil belajar yaitu faktor internal dan faktor eksternal. Faktor internal merupakan faktor yang berasal dari dalam diri siswa itu sendiri, seperti kecerdasan, kemampuan berpikir kritis, motivasi, kesehatan, dan cara belajar, serta kemandirian belajar, sedangkan faktor eksternal merupakan faktor yang datang dari luar diri siswa, seperti lingkungan keluarga, lingkungan sekolah, dan lingkungan masyarakat. Kemandirian belajar merupakan salah satu faktor internal yang memengaruhi hasil belajar.

Adapun menurut Makki \& Aflahah (Hae, Tantu, \& Widiastuti, 2021) mengatakan bahwa motivasi belajar sangat menentukan tingkat pencapaian hasil belajar anak. Motivasi adalah suatu perubahan energi didalam pribadi seseorang yang ditandai dengan timbulnya efektif (perasaan) dan reaksi untuk mencapai tujuan (Harahap, et al., 2021). Menurut (Zulfiana, 2014) perubahan energi dapat berupa perubahan kegiatan fisik. Karena seseorang mempunyai tujuan tertentu dari aktifitasnya, maka seseorang mempunyai motivasi yang kuat untuk mencapainya dengan segala upaya yang dapat dia lakukan untuk mencapainya.

Sebelum adanya penelitian ini, sudah ada beberapa penelitian atau tulisan yang telah dilakukan oleh beberapa peneliti terdahulu yaitu tentang pengaruh motivasi terhadap hasil belajar siswa. Penelitian yang dilakukan oleh (Zulfiana, 2014), dengan judul Korelasi Motivasi Belajar Pendidikan Agama Islam terhadap Hasil Belajar Siswa di Sekolah Menengah Pertama Negeri 5 Muara Bungo dengan hasil bahwa prestasi pelajaran PAI ditentukan oleh motivasi sebesar 20,25\% sedangkan 79,75\% ditentukan oleh hal lain, hal tersebut disebabkan karena Sekolah Menengah Pertama Negeri 5 Muara Bungo hanya menyediakan waktu 2 jam untuk mempelajari bidang studi pendidikan agama Islam. Penelitian oleh (Purnama, 2013) dengan judul motivasi belajar dari Sekolah Ilmu Kesehatan Insan Cendikia Husada Bojonegoro. Dengan hasil bahwa motivasi dalam belajar mempengaruhi pada hasil dari proses belajar,motivasi berperang sebagai pendorong semangat dalam proses belajar.Penelitian oleh (Stevany, 2012) dengan judul pengaruh Motivasi terhadap prestasi belajar siswa kelas VIII SMP Negeri Sekecamatan Bantul dengan hasil bahwa prestasi belajar siswa ditentukan oleh motivasi sebesar 40,25\% sedangkan 59,75\% ditentukan oleh hal lain.

Kerangka Pemikiran pada penelitian ini yaitu

$\mathrm{x} 1 \quad \mathrm{x} 2$

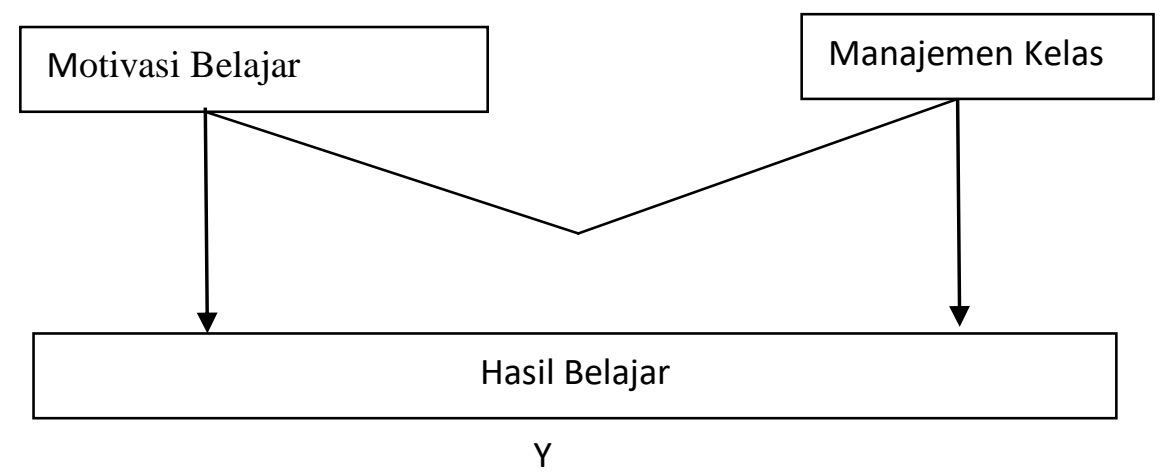

Gambar 1. Kerangka Pemıkiran 


\section{METODE PENELITIAN}

Pendekatan pada penelitian ini yaitu kuantitatif korelasi digunakan untuk menghitung, menggambarkan, dan menggali tentang pengaruh motivasi ekstern terhadap hasil belajar siswa (Dantes \& Nyoman, 2012). Populasi adalah suatu kumpulan menyeluruh dari suatu objek yang merupakan perhatian dalam penelitian (Martono \& Nanang, 2010). Populasi penelitian adalah seluruh siswa Madrasah Tsanawiyah X kabupaten Tebo yang berjumlah 117 orang. Sampel adalah bagian dari jumlah dan karekteristik yang dimiliki oleh populasi tersebut (Martono \& Nanang, 2010). Sampel yang digunakan dalam penelitian ini adalah siswa kelas VIII A dan VIII B MTs X Rimbo Bujang yang berjumlah 43 orang.

Metode sampling yang digunakan dalam penelitian ini adalah Non Probability sampling. Menurut (Marchali, 2018) Non probability sampling yaitu teknik pengambilan sampel yang tidak memberi peluang atau kesempatan samabagi setiap unsur atau anggota populasi untuk dipilih menjadi anggota sampel. Sampel yang digunakan dalam penelitian ini yaitu kelas VIII MTs X Kabupaten Tebo. Dalam pengumpulan data peneliti melakukannya dengan langkah pertama dan utama yaitu dengan melakukan observasi pada madrasah yang di tujusebagai landasan utama mengapa di pelukannya penelitian ini.

Setelah melakukan obsevasi denganhasil yang di peroleh maka peneliti melanjutkannya dengan proses penelitian langsung di lapangan dengan menggunakan metode angket, dimana dalam metode ini peneliti mengukur hal-hal yang telah dipaparkan sebelumnya dalam latar belakang penelitian ini. Setelah menggunakan angket nantinya peneliti akan melakukan anasisi hasil dari angket yang tadinya sudah di isi oleh siswa melalui perhitungan secara langsung maupun perhitungan menggunakan bantuan aplikasi SPSS (Statistical Product and Service Solutions). Setelah hasil didapatkan maka peneliti nantinya dapat memaparkan apakah hipotesis dari penelitian ini terjawab. Dan natinya dapat menajadi sebagai bahan masukan terhadap madrasah guna meningkatkan pemebelajran yang lebih baik lagi.

Adapun instrumen yang digunakan dalam penelitian menggunakan pedoman observasi, angket serta dokumentasi. Pedoman observasi digunakan sebagai alat bantu yang digunakan peneliti ketika mengumpulkan data melalui pengamatan dan pencatatan terhadap variabel yang diteliti. Sedangkan angket merupakan alat bantu yang dipakai peneliti untukmendapatkan data tentang korelasi. Angket terdiri dari 35 butir pertanyaan yang diajukan kepada siswa dengan rincian 20 soal bersifat positif dan 15 soal bersifat negatif dan yang terakhir adalah dokumentasi yaitu alat bantu peneliti berupa data foto kegiatan dalam penelitian serta data hasil belajar siswa pada mata pelajaran Aqidah Akhlak.

Pengujian Validitas dan reabilitas instrumen angket dilakukan menggunakan program aplikasi SPSS 16. Uji normalitas dilakukan terlebih dahulu dengan menggunakan One sample kolmogorv-Smirnov Tes. untuk dapat mendeteksi ada atau tidaknya multikolinieritas di dalam model regresi adalah melihat nilaiTolerance dan VIF ( Variance Inflation Factor) melalui program SPSS. Uji heteroskedastisitas dilakukan untuk menguji apakah dalam sebuah model regresi telah terjadi ketidaksamaan varian dari residual suatu pengamatan ke pengamatan yang lain. Uji Goodness of Fit atau uji kelayakan model digunakan untuk mengukur ketepatan fungsi regresi sampel dalam menaksir nilai aktual. Secara statistik uji Goodness of Fit dapat dilakukan melalui pengukuran nilai koefisien determinasi, nilai statistik F dan nilai statistik t.

Uji signifikasi simultan F dilakukan untuk mengetahui pengaruh variable independen (Motivasi Belajar dan Manajemen Kelas) terhadap variabel dependen (Hasil belajar). Uji t dikenal dengan uji parsial, yaitu untuk menguji bagaimana pengaruh masing-masing variabel bebasnya secara sendiri-sendiri terhadap variable terikatnya.

\section{HASIL DAN PEMBAHASAN PENELITIAN}

Pembahasan hasil penelitian ini dilakukan agar dapat memberikan penjelasan dan gambaran sehingga dapat memberikan pemahaman mengenai hasil dari penelitian. Pembahasan ini berisi kajian mengenai hasil temuan yang berhubungan dengan penelitian sehingga dapat diketahui terdapat pengaruh atau tidaknya antara motivasi dan manajemen kelas terhadap hasil belajar. Sehubungan dengan penelitian yang telah dilakukan, 
maka akan dikemukakan beberapa hasil penelitian. Dalam penelitian ini menunjukan hasil bahwasannya hasil belajar siswa di pengaruhi oleh motivasi manajemen kelas. Hasil dari penelitian tersebut akan dibahas secara tepat dan sesuai dengan hasil yang telah didapatkan oleh peneliti dari penelitian yang telah dilakukan pada madrasah tersebut.

Tabel 1. Hasil Uji Reabilitas

\begin{tabular}{|l|l|l|}
\hline Variabel & $\begin{array}{l}\text { Cronbach's } \\
\text { Alpha }\end{array}$ & Keterangan \\
\hline Motivasi (X1) & 0.826 & Reliabel \\
\hline Manajemen Kelas (X2) & 0.826 & Reliabel \\
\hline Hasil Belajar (Y) & 0.921 & Reliabel \\
\hline
\end{tabular}

Berdasarkan hasil uji reliabilitas didapatkan hasil berupa variabel motivasi belajar (X1) dengan nilai 0,826. Nilai ini lebih besar dari pada 0,60 sehingga untuk variabel motivasi belajar (X1) dinyatakan reliabel, sedangkan variabel manajemen kelas (X2) memiliki hasil pengujian dengan nilai 0,826 sehingga juga dikatakan reliabel karena nilainya diatas 0,60 dan variabel hasil belajar $(\mathrm{Y})$ memiliki hasil pengolahan data sebesar 0,921 sehingga nilainya juga lebih dari 0,60 dan dinyatakan reliabel. Hasil ini menunjukan bahwa variable motivasi belajar (X1), motivasi belajar (X2) Dan hasil belajar(Y) memiliki kesamaan yaitu reliabel yang artinya instrumen penelitian yang digunakan pada penenelitian ini dinyatakan konsisten.

Tabel 2. Hasil Uji Normalitas

\begin{tabular}{|l|l|l|}
\hline \multicolumn{2}{|l|}{ One-Sample Kolmogorov-Smirnov Test } \\
\hline \multicolumn{2}{|l|}{} & $\begin{array}{l}\text { Unstandardize } \\
\text { d Residual }\end{array}$ \\
\hline $\mathrm{N}$ & Mean & 22 \\
\cline { 3 - 4 } Normal Parameters ${ }^{\mathrm{a}}$ & Std. Deviation & .0000000 \\
\hline \multirow{2}{*}{$\begin{array}{l}\text { Most Extreme } \\
\text { Differences }\end{array}$} & Absolute & 3.00215562 \\
\cline { 2 - 3 } & Positive & .115 \\
\cline { 2 - 3 } & Negative & -.115 \\
\hline Kolmogorov-Smirnov Z & & .539 \\
\hline Asymp. Sig. (2-tailed) & .933 \\
\hline a. Test distribution is Normal. & \\
\hline
\end{tabular}

Berdasarkan tabel hasil uji normalitas diperoleh nilai Asymp.Sig (2 tailed) lebih besar dari pada taraf kepercayaan 5\% yaitu 0,933 hal ini lebih besar nilainya 0,005 sehingga data penelitian dikategorikan berdistribusi normal. Pada pengujian asumsi multikolinearista didapatkan hasil bahwa nilai tolerance dari motivasi belajar (X1) dan menajemen kelas (X2) sebesar 0,369 artinya nilainya lebih dari 0,1.

Tabel 3. Uji Asumsi Multikolinearista

\begin{tabular}{|l|l|l|l|}
\hline \multicolumn{2}{|l|}{ Coefficients $^{\mathbf{a}}$} & \multicolumn{2}{l|}{ Collinearity Statistics } \\
\cline { 3 - 4 } \multicolumn{2}{|l|}{ Model } & Tolerance & VIF \\
\hline 1 & (Constant) & & \\
\hline
\end{tabular}




\begin{tabular}{|l|l|l|l|}
\hline & Motivasi Belajar & .369 & 2.714 \\
\cline { 2 - 4 } & Manajemen Kelas & .369 & 2.714 \\
\hline \multicolumn{2}{|l|}{ a. Dependent Variable: Hasil Belajar } & \multicolumn{2}{|l}{} \\
\hline
\end{tabular}

Dari table uji asumsi multikolinearista nilai VIF (Variace Inflation Factor) sebesar 2,714, nilai ini kurang dari 10. Oleh sebab itu maka dinyatakan tidak terjadi gejala multikolenieritas karena nilai tolerance $>0,01$ dan nilai VIF $<10$.

\section{Tabel 4. Uji Heteroskedastisitas}

\section{Coefficients $^{\mathrm{a}}$}

\begin{tabular}{|c|c|c|c|c|c|}
\hline \multirow[b]{2}{*}{ Model } & \multicolumn{2}{|c|}{ Unstandardized Coefficients } & \multirow{2}{*}{$\frac{\text { Standardized Coefficients }}{\text { Beta }}$} & \multirow{2}{*}{ t } & \multirow[b]{2}{*}{ Sig. } \\
\hline & B & Std. Error & & & \\
\hline 1 (Constant) & 3.084 & 4.083 & & .755 & .459 \\
\hline Motivasi Belajar & .002 & .118 & .005 & 013 & 990 \\
\hline Manajemen Kelas & -.012 & .106 & -.042 & -.110 & .914 \\
\hline
\end{tabular}

a. Dependent Variable: Absres

Pada hasil pengujian heteroskedastisitas yang bertujuan untuk menguji apakah dalam sebuah model regresi terjadi ketidaksamaan variasi dari residual suatu pengamatan kepengamatan yang lain didapatkan bahwa hasil variable motivasi belajar (X1) sebesar 0,990. Dan nilai dari variabel manajemen kelas (X2) di dapatkan jumlah nilai sebesar 0,914. Dari hasil ini dapat dikatakan bahwa variabel motivasi belajar (X1) dan manajemen kelas (X2) tidak berpengaruh signifikan terhadap absolut residu dengan nilai signifikan 0,05 yang artinya tidak mengalami gejala heteroskasdisitas.

Tabel 5. Uji Goodness Of Fit

\begin{tabular}{|l|l|l|l|l|}
\hline \multicolumn{4}{|l|}{ Model Summary } \\
\hline Model & R & R Square & Adjusted R Square & Std. Error of the Estimate \\
\hline 1 & $\mathbf{. 9 7 1}^{\text {a }}$ & .943 & .937 & 3.15621 \\
\hline a. Predictors: (Constant), Manajemen Kelas, Motivasi Belajar \\
\hline \multicolumn{2}{|l|}{ b. Dependent Variable: Hasil Belajar } & \multicolumn{2}{l}{} \\
\hline
\end{tabular}

Dari pengujian Goodness Of Fit didapatkan hasil berupa R sebesar 0,971, hal ini menunjukan bahwa korelasi atau hubungan antara variabel dependen (hasil belajar) dengan nilai variabel independen (motivasi belajar dan manajemen kelas) termasuk dalam kategori sangat kuat. Angka koefisien determinasi R2 yang dihasilkan sebesar 0,943 artinya 94,3\% variasi dari hasil belajar mampu dijelaskan oleh variabel motivasi belajar dan manajemen kelas yang digunakan dalam persamaan regresi, sedangkan sisanya sebesar 4,7\% dijelaskan oleh variabel lain diluar penelitian ini. 
1457 Pengaruh Motivasi Belajar dan Manajemen Kelas terhadap Hasil Belajar Siswa - Agung Hidayatullah DOI: https://doi.org/10.31004/edukatif.v3i4.620

Tabel 6. Daftar Hasil Signifikasi Simultan F

\begin{tabular}{|c|c|c|c|c|c|c|}
\hline \multicolumn{7}{|c|}{ ANOVA $^{b}$} \\
\hline \multicolumn{2}{|c|}{ Model } & Sum of Squares & df & Mean Square & $\mathrm{F}$ & Sig. \\
\hline \multirow[t]{3}{*}{1} & Regression & 3105.683 & 2 & 1552.841 & 155.882 & $.000^{\mathrm{a}}$ \\
\hline & Residual & 189.272 & 19 & 9.962 & & \\
\hline & Total & 3294.955 & 21 & & & \\
\hline \multicolumn{5}{|c|}{ a. Predictors: (Constant), Manajemen Kelas, Motivasi Belajar } & & \\
\hline \multicolumn{4}{|c|}{ b. Dependent Variable: Hasil Belajar } & & & \\
\hline
\end{tabular}

Hasil uji $\mathrm{F}$ didapatkan nilai signifikasi 0,000 , karena nilai signifikasinya lebih kecil dari 0,05 $(0,000<0,05)$ maka dapat dikatakan bahwa variabel motivasi belajar (X1) dan manajemen kelas (X2) secara simultan atau bersama-sama berpengaruh secara signifikan terhadap variabel hasil belajar (Y).

Hal ini diperkuat kembali menggunakan hasil uji T parsial dengan hasil bahwa variabel motivasi belajar (X1) memiliki nilai signifikasi sebesar 0,000 lebih kecil dari 0,05, sehingga variabel motivasi belajar (X1) dinyatakan berpengaruh secara signifikan terhadap variabel hasil belajar (Y) hasil penelitian ini sejalan dengan hasil penelitian yang dilakukan oleh (Zulfiana, 2014) tentang korelasi motivasi belajar Pendidikan Agama Islam terhadap hasil belajar siswa di Sekolah Menengah Pertama Negeri 5 Muara Bungo dengan hasil penelitian motivasi belajar berpengaruh secara signifikan terhadap hasil belajar siswa. Variabel manajemen kelas (X2) memiliki nilai signifikasi sebesar 0,000 lebih kecil dari pada 0,05 sehingga variabel manajemen kelas juga berpengaruh secara signifikan terhadap hasil belajar (Y) hasil penelitian ini sejalan dengan hasil penelitian yang dilakukan oleh (Husnul, 2017) tentang manajemen kelas dalam pembelajaran Matematika Di SMA Negeri Yogyakarta hasil temuan manajemen kelas berpengaruh secara signifikan terhadap hasil belajar siswa.

Adapun makna sumbangan terhadap kemajuan ilmu pengetahuan diharapkan dapat bermanfaat terutama dalam hal dapat menjadi bahan acuan untuk kegiatan pendidikan, terutama dalam upaya perbaikan dan peningkatan mutu pendidikan yang mengarah pada peningkatan kinerja guru, digunakan sebagai sumbang saran dalam meningkatkan dan mengembangkan peran kepemimpinan kepala sekolah khususnya yang berpengaruh langsung pada peningkatan kinerja guru, sehingga guru dapat bekerja dengan penuh kerelaan, bersemangat, dan siap bersaing dengan sekolah lain. Diharapkan dapat bermanfaat bagi kepala sekolah dijadikan pertimbangan dalam menentukan wali kelas agar terciptanya guru bekerja dengan nyaman, aman, kreatif, dan menyenangkan, serta memberdayakan potensi yang dimiliki sekolah, dalam rangka menunjang kualitas pendidikan di sekolah. Bagi guru dapat meningkatkan kinerjanya dalam pengelolaan pembelajaran dan pengelolaan kelas yang dimotivasi oleh pimpinan sekolah agar dapat bekerja dengan efektif, efesien, nyaman, aman, berinovasai kerja tinggi, dan siap bersaing dengan sekolah lain.

Batasan temuan penelitian ini yaitu pada kelas VIII Madrasah Tsanawiyah X Kecamatan Rimbo Bujang dan pada mata pelajaran Aqidah Akhlak pada tahap kelas inilah tahap dimana siswa sangat memerlukan adanya motivasi dalam belajar. Pada penelitian ini membatasi pada motivasi belajar, peran guru dalam menajemen kelas dalam upaya mencapai hasil dari belajar siswa.

\section{KESIMPULAN}

Dari hasil penelitian dapat disimpulkan bahwa variabel motivasi belajar (X1) berpengaruh signifikan terhadap variable hasil belajar (Y). hal ini di buktikan dengan adanya hasil uji T Parsial dengan hasil nilai signifikasi sebesar 0,000 lebih kecil dari 0,05. Hal tersebut menjawab pertanyaan peneliti pada rumusan 
masalah tentang adakah pengaruh motivasi belajar yang signifikan terhadap hasil belajar siswa di madrasah tsanawiyah X kabupaten tebo. Variabel manajemen kelas (X2) berpengaruh signifikan terhadap variable hasil belajar (Y), hal ini dibuktikan dengan adanya hasil uji T Parsial dengan hasil nilai signifikasi sebesar 0,000 lebih kecil dari 0,05. Hal tersebut menjawab pertanyaan peneliti pada rumusan masalah tentang adakah pengaruh manajemen kelas yang signifikan terhadap hasil belajar siswa di madrasah tsanawiyah X kabupaten tebo. Variabel motivasi belajar (X1) dan manajemen kelas (X2) berpengaruh signifikan terhadap variabel hasil belajar (Y). Hal ini di kuatkan dengan bukti adanya hasil uji Simultan F dengan hasil nilai signifikasi 0,000, nilai ini lebih kecil dari 0,05 maka dapat dikatakan bahwa variable indenpenden ( motivasi belajar dan manajemen kelas) secara simultanatau bersama-sama berpengaruh signifikan terhadap variabel dependen (hasil belajar).

\section{UCAPAN TERIMA KASIH}

Dalam penyelesaian Tesis ini penulis telah banyak mendapatkan bantuan dan bimbingan dari berbagai pihak, sebagai ucapan terimakasih yang tiada terhingga di tujukan kepada yang terhormat bapak Prof. Drs. H. Sutrisno, M. Sc., PH. D selaku Rektor Universitas Jambi, bapak Prof. Dr. H. Haryadi, SE, MMS selaku Direktur Pascasarjana Universitas Jambim Ibu Dr. Hj. Muazza, M.Si selaku Ketua Program Pendidikan Magister Manajemen Pendidikan Universitas Jambi, bapak Dr. K. A Rahman, M. Pd. I selaku pembimbing I yang telah memberikan pemikiran, koreksi, bimbingan arahan serta motivasi dalam penyelesaian Tesis ini. Ibu Dr. Masbirorotni, M. Sc. Ed selaku pembimbing II yang telah memberikan pemikiran, koreksi, bimbingan arahan serta motivasi dalam penyelesaian Tesis ini, bapak dan ibu dosen serta seluruh civitas akademik Pascasarjana Megister Manajemen Pendidikan Universitas Jambi, bapak kepala Madrasah Tsanawiyah bapak Budiarto, SH, bapak guru mata pelajaran Aqidah Akhlak Bapak Muhammad Ali Mu'min, S. Pd. I. Semoga bantuan dan dorongan serta bimbingan yang telah diberikan kepada penulis dapat diterima sebagai amal shalehnya disisi Allah SWT.

\section{DAFTAR PUSTAKA}

Dantes, \& Nyoman. (2012). Metode Penelitian. Yogyakarta: Andi.

Dimyati, \& Mudjiono. (2019). Belajar Dan Pembelajaran. Jakarta: Rineka.

Djabidi, F. (2017). Manajemen Pengelolaan Kelas. Jakarta: Intrans Publishing.

Emmer, C. M. (2011). Manajemen Kelas Untuk Guru Sekolah Dasar. Jakarta: Kencana Prenada Media Group.

Enkoswara. (2011). Administrasi Pendidikan. Bandung: Alfabeta.

Erwinsyah, A. (2017). Manajemen Kelas Dalam Meningkatkan Efektifitasproses Belajar Mengajar. Tadbir : Jurnal Manajemen Pendidikan Islam, 5(2).

Euis, K. (2015). Manajemen Kelas Classroom Management. Bandung: Alfabeta.

Farel, G., Ambiyar, Simatupang, W., Giatman, M., \& Syahril. (2021). Analisis Efektivitas Pembelajaran Daring pada SMKdengan Metode Asynchronous dan Synchronous. EDUKATIF: JURNAL ILMU PENDIDIKAN, 3, 1185 - 1190. Retrieved from https://edukatif.org/index.php/edukatif/index

Gunawan, I. (2019). Manajemen Pendidikan. Bandung: Alfabeta.

Hae, Y., Tantu, Y. R., \& Widiastuti. (2021). Penerapan Media Pembelajaran Visual dalam Membangun Motivasi Belajar Siswa Sekolah Dasar. EDUKATIF : JURNAL ILMU PENDIDIKAN, 3(4). doi:https://edukatif.org/index.php/edukatif/index

Harahap, H. S., Hrp, N. A., Nasution, I. B., Harahap, A., Harahap, A., \& Harahap, A. (2021). Hubungan Motivasi Berprestasi, Minat dan Perhatian Orang Terhadap Kemandirian Siswa. EDUKATIF: JURNAL ILMU PENDIDIKAN, 3(4). doi:https://doi.org/10.31004/edukatif.v3i4.463 
1459 Pengaruh Motivasi Belajar dan Manajemen Kelas terhadap Hasil Belajar Siswa - Agung Hidayatullah DOI: https://doi.org/10.31004/edukatif.v3i4.620

Husnul. (2017). Manajemen Kelas Dalam Pemebelajaran Matematika di Sma Yogyakarta. Jurnal Peneitian. Imam, A. (2013). Pengelolaan kelas dari teori ke praktek. Yogyakarta: Insyira.

Marchali, I. (2018). Statistik Itu Mudah. Yogyakarta: Lembaga Ladang.

Martono, \& Nanang. (2010). Metode Penelitian Kuantitatif. Jakarta: PT Raya Grafindo Persada.

MoEC. (2013). Peraturan menteri pendidikan dan kebudayaan republik Indonesia nomor 65/2013 tentang standar proses pendidikan dasar dan menengah [The decree of the minister of education and culture no 65/2013 on the standards for primary and middle education]. Jakarta: Kementerian Pendidikan.

Muhammad, M. (2016). Pengaruh Motivasi Dalam Pembelajaran. Lantanida Journal, Vol. 4 No. 2, 2016, 4(2).

Muhibin, S. (2014). Psikologi Pendidikan Dengan Pendekatan Baru. Bandung: PT Remaja Rosdakarya.

Nurlina, I. (2010). Pengaruh Manajemen Kelas Dan Etos Kerja Terhadap Efektivitas Proses Belajar Mengajar Guru Sekolah Dasar Di Kecamatan Babakan Cikao Kabupaten Purwakarta. Jurnal Admisistrasi Pendidikan Universitas Pendidikan Indonesia, 12. Retrieved from https://ejournal.upi.edu/index.php/JAPSPs/article/view/6380/4338

Nurrohma, R. I., \& Adistana, G. A. (2021). Penerapan Model Pembelajaran Problem Based Learning dengan Media E-Learning Melalui Aplikasi. EDUKATIF: JURNAL ILMU PENDIDIKAN, 3(4). doi:https://doi.org/10.31004/edukatif.v3i4.544

Patmawati; Yunus, Muh; Devilla, Rego; Yahya, Muh. (2018). Pengaruh Manajemen Kelas Dan Etos Kerja Guru Terhadap Efektivitas Pembelajaran Di Smp Negeri 1 Parepare. Jurnal Ilmiah Pena Sains dan Ilmu Pendidikan, 10.

Pebrianto, Herpratiwi, \& Fitriawan, H. (2021). Pengembangan Multimedia Pembelajaran Hari Raya Agama Buddhadi Sekolah Minggu Buddhis Bodhisattva. EDUKATIF: JURNAL ILMU PENDIDIKAN, 3, 1261 - 1270. Retrieved from https://edukatif.org/index.php/edukatif/index

Purnama, N. I. (2013). Motivasi Belajar. Jurnal Penelitian.

Riyanti, Y., Wahyudi, \& Suhartono. (2021). Pengaruh Kemandirian Belajar Terhadap Hasil Belajar Matematika Siswa Sekolah Dasar. EDUKATIF: JURNAL ILMU PENDIDIKAN, 3(4).

Stevany. (2012). Pengaruh Motivasi Terhadap Prestasi Belajar Siswa Kelas Vlll Smp Negeri Sekecamatan Bantul. Jurnal Penelitian.

Supradyani, d. (2013). Kontribusi Kemampuan Manajemen Kelas, Etos Kerja Dan Pemanfaatan Media Belajar Terhadap Efektifitas Pembelajaran. e-Journal Program Pascasarjana Universitas Pendidikan Ganesha Program Studi Administrasi Pendidikan, 4.

Suyono. (2012). Belajar dan Pembelajaran. Bandung: PT Remaja Rosdakarya.

Wahid, I. A. (2016). Pengaruh Motivasi, Etos Kerja Dan Disiplin Kerja Terhadap Kinerja Pegawai Negeri Sipil (Pns) Pada Dinas Kehutanan Dan Perkebunan Daerah Kabupaten Morowali. Jurnal Katalogis, Volume 4 Nomor 8, Agustus 2016 hlm 156-163, 4. Retrieved from https://media.neliti.com > media > publications

Wiyani, \& Ardy, N. (2013). Manajemen Kelas. Yogyakarta: Ar-Ruzz Media.

Yusuf, R. N., Musyadad, V. F., Iskandar, Y. Z., \& Widiawati, D. (2021). Implikasi Asumsi Konsep Diri Dalam Pembelajaran Orang Dewasa. EDUKATIF : JURNAL ILMU PENDIDIKAN, 3(4). doi:https://doi.org/10.31004/edukatif.v3i4.513

Zulfiana. (2014). Korelasi Motivasi Belajar Agama Islam Terhadap Hasil Belajar Siswa Disekolah Menengah Pertama Negeri 5 Muara Bungo. Jurnal Penelitian. 